\title{
11 Conglomerates and the Department of Energy promote coal development in the Philippines ${ }^{1}$
}

\author{
Niccolò Manych and Michael Jakob
}

\section{Introduction}

The Philippines are among the countries, which are turning into major coal consumers with a current coal pipeline (i.e. plants that are under construction, announced, permitted or under pre-permit development) of $9 \mathrm{GW}$, of which 2 GW are already under construction (Global Energy Monitor, 2021). This buildup of coal would lock in emissions for decades and severely undermine the transition to a clean energy system in the Philippines.

The need for a transition to renewable energy (RE) in the Philippines and barriers thereof has previously been addressed by several authors. Clark et al. (2020) look at the future of coal-fired power generation and find that aging infrastructure and geographic challenges may make renewables especially appealing in archipelagos like the Philippines. Model scenarios support this finding and demonstrate the potential of RE as a low-carbon energy source that helps to diversify the energy mix and reduce import dependence on fossil fuels (Mondal et al., 2018). Nevertheless, a successful transition to renewables largely depends on the speed and efficiency of energy policy reform (Brahim, 2014), since the current energy market dysfunction hinders the transition (Ahmed, 2019). Yet, Chapman et al. (2019) highlight a lack of political commitment to enable a low-carbon transformation.

Other chapters focus on actors and energy- and climate-related objectives in the Philippines. La Viña et al. (2018) analyze the perceived trade-offs between low-cost energy, reliability and environmental sustainability (i.e. the "energy policy trilemma"). Ravago and Roumasset (2016) argue that these conflicting objectives should be reconciled. Saculsan and Mori (2020) explain the prominent roles of regime incumbents (oligarchs and the government) as well as external actors, in contrast to Marquardt et al. (2016), who highlight the limited influence of international donors. La Viña et al. (2018) emphasize the important role of the government, and Marquardt and Delina (2019) discuss how a community-led social movement prevented the construction of a coalfired power plant.

However, none of the abovementioned contributions explicitly analyzes the interplay of numerous political economy factors in a systematic manner. 
Hence, our study is, to our knowledge, the first to examine the objectives of political as well as societal actors, the way how the specific country context influences policy-making and how this interplay results in an increasing role of coal in the power sector. We conduct our analysis from the perspective of the AOC ("actors, objectives, context") framework (Jakob et al., 2020) covered in Chapter 1.The analysis in this study uses novel interview data that reveal hitherto unavailable expert knowledge and allows to draw policy implications.

We carried out semi-structured expert interviews as described in Bogner et al. (2014). Drawing on desk research and pre-interviews, which we employed to test our interview guideline, we identified the most relevant stakeholders. In October and November 2019, we carried out 35 interviews with 50 stakeholders in Metro Manila. As only relatively few institutions declined our invitation, we were able to obtain interviews from a broad spectrum of stakeholders. We complied with ethical principles following an internal data management plan. To warrant their anonymity, we ensured all interview partners to publish their statements only in an aggregated and processed form. Refer to Online Appendix ${ }^{2}$ for the interview guideline and a list of all interviews.

Our analysis focuses on the interview data and is structured along key objectives. We clustered the objectives mentioned during the interviews into four high-level strategic objectives along which we carry out our analysis. We also draw on existing studies, newspaper articles, reports and announcements to assess whether statements from our interviews are confirmed by other authors' findings and provide additional relevant information. We interviewed several actors with presumably similar opinions to additionally allow for comparison of answers and interviewees. Interviews with researchers from different universities support the validation of answers.

\section{Country context}

In the following, we provide information on the historical development of the electricity sector and energy policy-making. We split the development of the electricity sector into four phases. The first three are discussed in the Online Appendix. The ongoing liberalization as the last phase is analyzed hereafter. The rise of coal power, which has been especially pronounced during the past decade, can be seen in Figure 11.1.

\section{The liberalization of the electricity sector}

The liberalization of the power sector is ongoing. The Electric Power Industry Reform Act of 2001 initiated unbundling and restructuring and resulted in an oligopoly (Congress of the Philippines, 2001). Consequently, the entire electricity supply chain in the Philippines is dominated by a few large conglomerates (Clark et al., 2020). For a detailed overview of the ownership structure and the conglomerates, refer to the Online Appendix. The Energy Regulatory Commission was founded to promote competition and oversees the Wholesale 


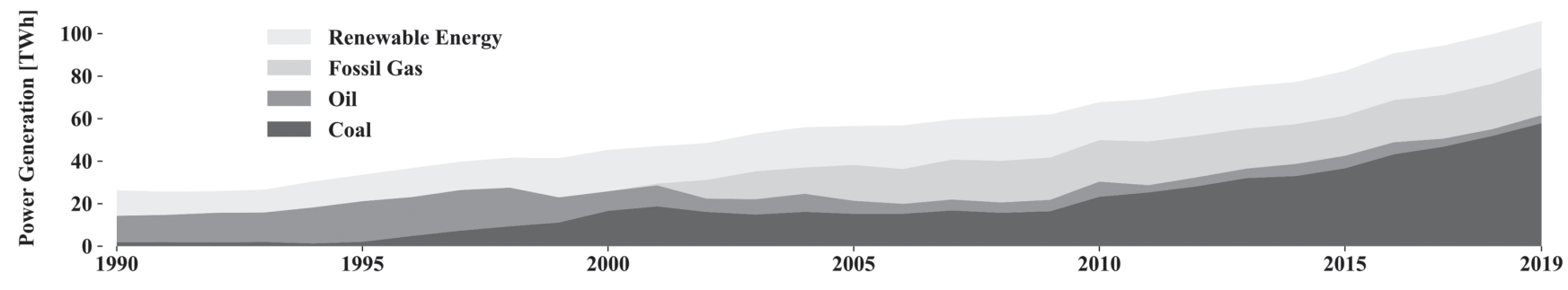

Figure 11.1 Power generation by major energy source, 1990-2019.

Source: Department of Energy (2018b, 2019a). 
Electricity Spot Market established in 2006. The market constitutes an alternative to Power Supply Agreements (PSAs), as Power Purchase Agreements are referred to in the Philippines. The Renewable Energy Act of 2008 is considered the first in Southeast Asia to act as comprehensive legislation on RE (IRENA, 2017). It mandated the Department of Energy (DOE) and the Energy Regulatory Commission to introduce a range of policy instruments like feed-in tariffs, net-metering and Renewable Portfolio Standards (Congress of the Philippines, 2008). The DOE develops the Philippine Energy Plan, which is seen as important guidance for the power sector. The most comprehensive version covers the period 2017-2040 and features a strong focus on coal (Department of Energy, 2017b, 2017a).

\section{Energy policy formulation, implementation and enforcement}

All three branches of government in the Philippines as well as societal actors play a part in the electricity sector governance. The legislative branch includes the Congress, which consists of the Senate and the House of Representatives. Political parties play a negligible role in Congress (Dressel, 2011). Energy laws are often proposed by the Senate's committee on energy, lobby groups or executive departments (Senate of the Philippines, 2019a). The executive branch includes the president, who serves a six-year term and cannot be reelected, the cabinet, 20 executive departments and multiple boards and commissions (National Government Portal, n.d.). The president occupies a very powerful position (Quimpo, 2007) and can pass executive orders, which has been the case in the electricity sector (President of the Philippines, 2017). The most important department for the power sector is the DOE. It oversees the implementation of laws and translates these into policies, often after consulting the private sector (Department of Energy, 2020b). NGOs and economic actors frequently file lawsuits against regulations in the power sector. The civil society moreover opposes power plants on the ground, which in many cases met with violence (global witness, 2019). Local Governmental Units hold executive and legislative powers.

The separation of power is in practice undermined by oligarchic structures and powerful elites. President Duterte recently claimed that he "dismantled the oligarchy that controlled the country's economy" (CNN Philippines, 2020), which is contested (Lorenzana, 2020). Economic and political power lies in the hands of few families, rooted in colonial rule (McCoy, 2017). The importance of the family is incorporated in the "Padrino System" that governs the Filipino society (Wong, 2010). This results in political dynasties that make up the majority of elected representatives on the national level (Mendoza et al., 2012; Purdey et al., 2016). Elites further dominate the decision-making on local levels (Yilmaz \& Venugopal, 2013). 


\section{Results}

A variety of objectives influencing decision-making in the electricity sector were mentioned by the interviewees (see Online Appendix for a table of all objectives). We grouped these individual objectives into four main high-level objectives: Reducing energy poverty, energy security, ecological sustainability and private profits. This represents the energy policy trilemma with one additional objective for vested interests of conglomerates. Key actors in the electricity sector include political actors (denoted as "p" throughout the study) and societal actors. The latter is divided into economic actors ("e"), other societal actors international such as international agencies ("si"), and other societal actors national, for example, NGOs and researchers ("sn"). Figure 11.2 shows the share of interviewees from each actor group that mentioned each respective objective. The graph allows differentiating between objectives stated as being relevant for the decision-making in the power sector in general (a) and the interviewees' (or their institutions') own goals (b). This differentiation sheds some light on the discrepancy between officially announced and perceived objectives.

Each mentioned objective within the four main objectives is analyzed hereafter with a focus on relevant actors, related policy instruments and the impact on the development of coal. Where identified, we additionally mention why a specific objective is relevant to an actor.

\section{Reducing energy poverty}

Two sub-objectives of reducing energy poverty were raised by the interviewees, expanding electricity access and ensuring affordable electricity. These are interlinked, as often the most expensive electricity is provided to the poorest households in rural areas and regions with lower income are more often experiencing a lack of access to electricity and electric devices (Mendoza et al., 2019). While the goal of electricity access favors the use of renewables, affordability is often used as an argument for coal.

\section{Expanding electricity access}

Electrification in the Philippines is primarily driven by political actors through RE. In 2019, around 1.5 million households out of the total number of 22.7 million were not connected to the power grid, foremost in rural areas in Mindanao (Department of Energy, 2018a). Electrification is in most cases not profitable for the private sector and thus initiated by the government and consumer-owned electric cooperatives for human development and economic growth [sn3, si3]. It is also seen as a measure to improve the conditions in rural areas in order to decongest Metro Manila [si2]. The DOE (2017e) thus aims at achieving 100\% electrification by 2022 for households with grid access, while all off-grid areas are envisaged to have electricity access by 2040. The 
(a)

$$
100 \%
$$

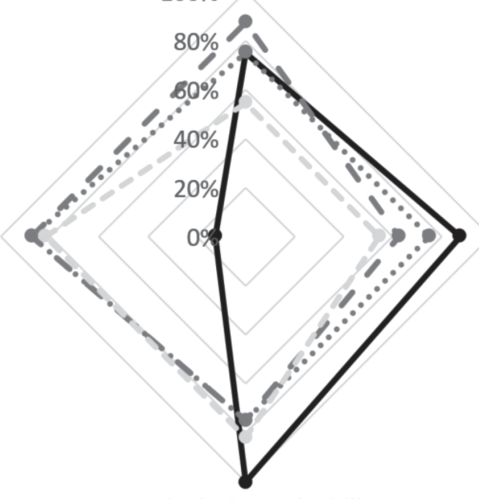

3. Ecological sustainability (b)

\section{Energy}

security

\section{$\longrightarrow$ political actors}

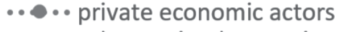

- - other societal actors international

- other societal actors national
1. Reducing energy poverty

$$
100 \%
$$

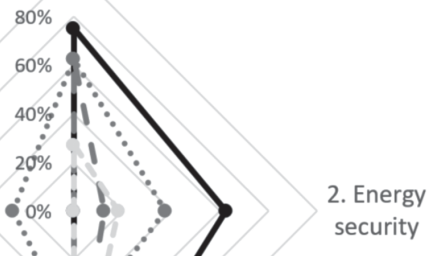

3. Ecological sustainability

Figure 11.2 Share of interviewees from each group referring to the four main objectives affecting the power sector.

Note: (a) shows the objectives that interviewees stated as being important for the decision-making in general, which includes perceived objectives of other actors, (b) shows the objectives mentioned by the interviewees as their own objectives or those of their institutions. 
two main agencies to perform the rural electrification are the National Power Corporation and the National Electrification Administration with support of international agencies (GIZ, 2019). To increase electricity access, the government supports microgrids (Senate of the Philippines, 2019b) as this objective can be best achieved with decentralized RE (Bertheau \& Cader, 2019) [si3, e5, si8, si5].

\section{Affordability}

The Philippines are subject to high electricity prices for various reasons, for example, the oligarchic structure in the electricity sector. At around $0.20 \mathrm{US} \$$ / $\mathrm{kWh}$, tariffs are among the highest in Asia (Ahmed, 2019). This constitutes difficulties for private consumers and the manufacturing sector (Ravago et al., 2016, 2019) [p1]. Stated reasons for the high prices include expensive PSAs with foreign generation companies in the 1990s to overcome power crises [si2], high feed-in tariffs (La Viña et al., 2018), as well as charges for rural electrification and the National Power Corporation's outstanding debt (Congress of the Philippines, 2001). Another reason is the lack of competition in the power sector. The Electric Power Industry Reform Act aimed at liberalizing the market and reducing tariffs but actually "consolidated the sector into the hands of a few companies" [si6] while tariffs remained high. One of the reasons is that many of the government's privatized power plants were purchased by incumbents (Rudnick \& Velasquez, 2019). The resulting oligarchy controls the sector and does not promote competition (Roxas \& Santiago, 2010). Market entry of new players is in addition hampered by red tape [p4, e7] and regulatory uncertainty [e3].

Various policies have been passed to cut electricity tariffs - with limited success. The DOE sets limitations for market shares of companies, for example, $25 \%$ of the total installed capacity in the national grid for generation (Department of Energy, 2018a). President Duterte highlighted the need to further open up the market for international players (Ong \& Flores, 2016). The DOE (2017c) published a report on "Investment Opportunities in the Philippine Energy Sector", which explicitly invites foreign companies to enter the market. Maniego Jr. (2016) argues that, especially for RE, domestic companies have not yet gained sufficient experience and rely on foreign developers. The independent, quasi-judicial Energy Regulatory Commission - one of the most important actors when it comes to tariffs, which sets rates and approves PSAs - oversees all companies and the spot market and penalizes abuse of market power [p4]. The Energy Regulatory Commission passed net-metering regulations for electricity that is produced by consumers, for example, by means of solar home systems (Energy Regulatory Commission, 2013). However, the electricity is sold for blended generation charges, while the consumers have to pay the full price. This reduces the economic incentives for consumers and benefits distribution utilities [e5]. Thus, even though Congress passes laws to 
bring down tariffs and enhance competition, the implementation by the DOE and the Energy Regulatory Commission is flawed and tariffs remain high.

The high tariffs are used as an argument for coal because coal is by many perceived as the cheapest option. The highest share of the average consumer prices is generation charges of almost 50\% (Ravago et al., 2016). PSAs for coal currently often have lower rates compared to other baseload resources such as geothermal, hydropower and gas (La Viña et al., 2018). Nevertheless, the actual costs of coal power can be higher, as the rates in the PSAs for coal are not fixed and fluctuations of fuel costs are directly passed on to consumers, which is referred to as "automatic pass-through" [e5, sn10, p2, sn9]. The socioeconomic cost of coal, pricing in environmental and health externalities, is much higher than that of alternative sources [e5, p2, sn9]. In the past, some PSAs for solar have already been set at lower rates compared to coal (Shearer et al., 2018). Solar and wind plants have further reduced the spot market prices (Verzola et al., 2017). Gray et al. (2018) project that, before the end of this decade, it will be cheaper to build new solar capacity than to run existing coal plants. However, coal is still perceived as cheap by many politicians [si1, e6, p3], which can partly be explained by a study funded by the United States Agency for International Development (USAID) (Ravago et al., 2016) [sn3]. The authors argue that the share of coal in the Philippines' electricity mix should increase in order to bring down electricity tariffs. This opinion is shared, for example, by the Chamber of Commerce and Industry (The Philippine Star, 2017), the National Economic and Development Authority (2017) and president Duterte (Ong \& Flores, 2016). The objective of decreasing tariffs is thus a strong driver of coal.

\section{Energy security}

Three subcategories of energy security were mentioned by the interviewees: Grid stability and meeting growing electricity demand are drivers of coal, whereas reducing import dependency is favoring RE.

\section{Reliability and grid stability}

Power outages are a regular problem in the Philippines and their avoidance is thus high on the political agenda [si4, sn9, si2]. Outages occur due to increasing demand during the summer months [e5] and technical problems of coal plants (Department of Energy, 2019b). The Philippines cannot import electricity from neighboring countries to offset supply and demand shocks [sn11, e4]. Another difficulty is the three separate main grids in Luzon,Visayas and Mindanao, which are accompanied by a great number of microgrids (Bertheau \& Cader, 2019). The DOE tried to improve the situation by interconnecting the Luzon and Visayas grids (Department of Energy, 2018a), even though the capacity of the interconnection line might already be too small [e4].The DOE aims at creating an integrated system for the whole archipelago within its Transmission Master 
Plan, which could help to balance the oversupply of electricity on Mindanao with the lack of capacity in the north [sn11, e6].

To increase grid stability, the DOE favors large, non-intermittent baseload capacity [si4, sn11, p2, si3, sn2]. The baseload and reserve requirements have recently been increased (National Economic and Development Authority, 2017; Verzola, 2018). Some interview partners advocated the current approach [p5, e8, sn9]. Others stated that the DOE is clearly overestimating the country's baseload demand [sn5, si1, e1, si5, sn6, si3, e3]. One politician mentioned a new study that finds that the baseload requirement is actually lower than currently assumed [p8].

The DOE sees coal as a source to avoid power outages [sn7, sn5, si6], which also has to do with the lack of alternatives for baseload. Untapped geothermal capacity is often not viable due to economic or technical constraints [sn11, p7, p8]. The Nuclear Energy Program Implementing Organization was created in 2016 and is considering a collaboration with Russia (Romero, 2019). However, the Philippines frequently experience earthquakes [sn6] and show public resistance because of a nuclear power plant constructed during the Marcos era [si5]. The usage of liquefied natural gas (LNG) in anticipation of the depletion of the Malampaya gas field is on the energy agenda (Department of Energy, 2017e). A gas hub is therefore planned in the Batangas province [p8, e4]. None of these alternatives to coal is currently sufficiently available or expected to be so in the near future [p3, e4, si4, sn11]. The focus on baseload capacity creates a "vicious circle" [si1]: Due to the high share of firm coal in the electricity mix, intermittent RE can affect the grid stability (National Economic and Development Authority, 2017).

\section{Meet growing demand}

The Philippines is one of the fastest growing economies in Asia, which is perceived by many actors to be linked to coal. While the population grew by $1.7 \%$ on average per year from 2000 to 2018, the annual GDP growth rate for the same period was 8.1\% (The World Bank, 2019a, 2019b). Power generation in the Philippines grew on average by $4.9 \%$ annually from 1990 to 2019 (Department of Energy, 2018b, 2019a). In line with still low electricity consumption per capita compared to neighboring countries (The World Bank, 2014), the DOE's Philippine Energy Plan (2017d) projects a yearly increase in total consumption of $4 \%$ until 2040. This is backed by academic findings, for example, by Ravago et al. (2018). While the electricity supply from renewables is projected to increase by around 1.5\% annually until 2040, coal supply (mostly for power generation) is expected to increase by around $6 \%$ per year in the same period (Department of Energy, 2017b). New energy infrastructure is part of Duterte's overarching goal of economic development (Build Build Build, 2018), which is also important for political actors in the energy sector, like the Climate Change Commission and the DOE [si3, p6, si4]. One political actor 
told us that "our policy supports the economic agenda of the country" [p5].At the same time, coal is seen as a prerequisite for economic development [e4, sn 4 , p6,sn7, e8].This is in accordance with the large capacity of coal plants currently in the pipeline as shown in Figure 11.3.

Meeting the rapidly growing electricity demand is important for many political actors and is fostered through several policies that benefit coal. President Duterte (2020) and the National Economic and Development Authority (2017) promote the development of new power capacity. Instruments that streamline the application process of power projects are passed by the legislative (Congress of the Philippines, 2019) and the president in an executive order (President of the Philippines, 2017). The latter requires attributes that are hard to fulfill for RE projects, for example, the financial volume [sn4, sn9]. The DOE has shifted to a technology-neutral approach to increase capacity [si4, p2, p8, si4]. Together with the formerly mentioned baseload focus, this favors coal due to the current lack of alternatives for baseload energy [e3, p3, si7, sn5, si1, si5]. Furthermore, the government explicitly fosters the cooperation with foreign companies for coal: The Philippines are part of the Association of Southeast Asian Nations (ASEAN) Forum on Coal to enhance cooperation in the coal sector (Department of Energy, 2017e) and have partnered with the Japan Coal Energy Center for "technology transfer of Japan's [...] coal-fired power plants" (Department of Energy, 2017e). Policies favoring coal are in line with the abovementioned DOE's projections of RE and coal demand.

\section{Reduce dependence on energy imports}

Increasing self-sufficiency is an important argument in favor of RE and against coal and was stated foremost by political actors [p5, p1, p8]. The Philippines have few domestic coal and oil resources and rely heavily on imports. The current domestic coal production stemming from Semirara Island is mostly exported to China [p7]. At the same time, about $85 \%$ of the coal for the power sector is imported, almost exclusively from Indonesia (Department of Energy, 2020a). This creates a large market with 71 accredited coal traders in 2019 (Department of Energy, 2020d). Imports lead to a dependence on other countries and exposure to international market price fluctuations (La Viña et al., 2018). Self-sufficiency dropped in recent years due to increased usage of imported coal (Department of Energy, 2020c). The DOE (2017d) pursues the goal of attaining energy independence within its Philippine Energy Plan. This could be achieved with wind and solar as their potential domestic capacity is sufficient to power the country (IRENA, 2017).

\section{Ecological sustainability}

Two sub-objectives of ecological sustainability were mentioned, both of which promote RE over coal. However, the impact of these objectives is questionable. 

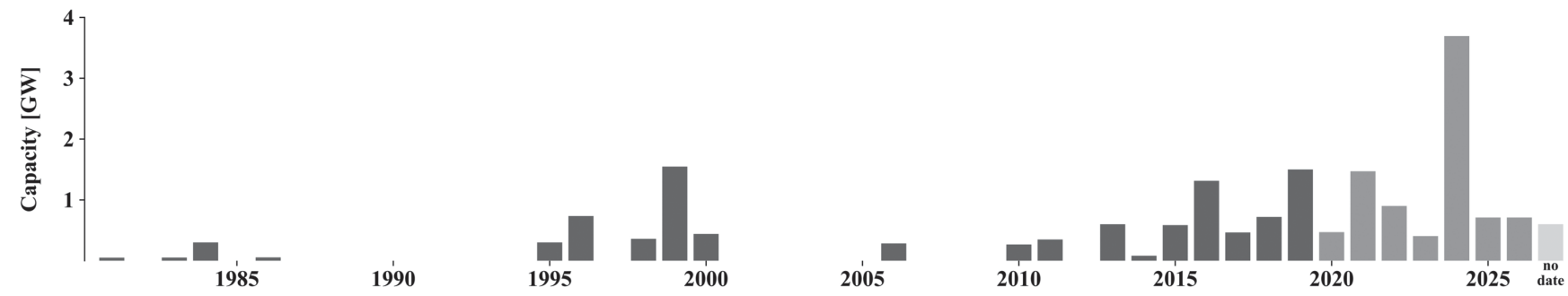

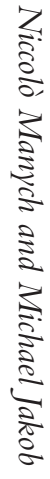

Figure 11.3 Capacity additions from coal-fired power plants per year.

Note: Plants from 2020 onward are currently in the pipeline.

Source: Own graph with data from the Global Energy Monitor (2021). 


\section{Climate change mitigation and adaptation}

The objective of adaptation is well aligned with the country's vulnerability to climate impacts and clearly favors RE. The Philippines are already today among the countries most affected by weather-related loss events (La Viña et al., 2018). Global warming will further increase the risk and occurrence of natural disasters (Fuentes Hutfilter et al., 2019; Holden, 2018) and exacerbate existing inequalities [si6]. This can be counteracted by several mechanisms to strengthen communities and local groups, especially indigenous communities [sn5, p5, sn10, p4]. Interviewees mentioned decentralized systems with renewables as the most promising approach to increase adaptive capacity [sn5, si6, e5, sn10, p6].

In light of the severe risk that climate change poses, different political and societal actors support mitigation policies. Local actions are often initiated by NGOs and social movements [sn10, sn4, si6]. Some Local Governmental Units, for example, on Negros, declared their provinces coal-free in order to ease the impact of climate change [sn5]. On a national level, the DOE set energy efficiency goals for each sector, aiming at a total reduction of $40 \%$ of energy intensity (compared to 2010 baseline) by 2030 (Department of Energy, 2016). The main policy body is the Climate Change Commission that develops mitigation frameworks and represents the country at all conferences and events on climate change (Climate Change Commission, 2012). The Climate Change Commission (and the Philippines in general) played an important role in securing the $1.5^{\circ} \mathrm{C}$ temperature target in the Paris Agreement with the Manila-Paris Declaration (ClimateVulnerable Forum, 2015): "the road to Paris started in Manila" [p6]. The Philippines' Intended Nationally Determined Contribution includes a 70\% of reduction (not specified by sector) by 2030 compared to the business-as-usual (BAU) scenario (which is likewise not specified) conditional on international financial support (Republic of the Philippines, 2015). More information on sustainable finance can be found in the Online Appendix.

The significance of those actions and their impact on coal is questionable. As of March 2021, the Philippines have not submitted their Nationally Determined Contribution (UNFCCC, 2020). Domestic emissions grew rapidly from $37 \mathrm{MtCO}_{2} \mathrm{e}$ in 1990 to $123 \mathrm{MtCO}_{2} \mathrm{e}$ in 2018 and are projected to increase further to reach $346 \mathrm{MtCO}_{2} \mathrm{e}$ in 2040 even under the government's Clean Energy Scenario (and $397 \mathrm{MtCO}_{2} \mathrm{e}$ in the BAU case) (Department of Energy, 2018b). The expected increase is primarily driven by power generation, which accounted for $52 \%$ - and more specifically by coal that accounted for $51 \%$ of the emissions in 2018 (Department of Energy, 2020c). This corresponds to the opinion of the Climate Change Commission (2012), the DOE (2020c) and many (political) interview partners that the Philippines are not responsible to limit their emissions due to their much lower historical emissions compared to industrialized nations [p5, p6, p8, p7]. 


\section{Reducing local air and water pollution}

Regardless of the support from society and NGOs, reducing local air and water pollution does not seem to influence national energy policy-making much. In the World Values Survey (2014), almost two-thirds of interviewed Filipinos agreed that it is important to protect the environment, even if this hampers economic growth. Two policies to enhance the quality of the environment are the Fisheries Code and the Philippine Clean Air Act. The latter recognizes the polluter pays principle and allows citizens to file an action in court against persons violating this act (Congress of the Philippines, 1999). The Environmental Impact Assessment for coal plants could restrict the construction of polluting coal plants [sn2, p4]. However, its review manual states that the "pursuit of socioeconomic development has equally important consideration for environmental protection" (Department of Environment and Natural Resources, 2007). The Philippine Clean Air act recommends the Department of Environment and Natural Resources to review emission standards every two years, which has not happened thus far and leads to weak standards for coal plants coupled with a lack of reliable monitoring stations [sn4]. One of the stated reasons for the lack of serious action is that the transport sectors - especially cars - are deemed to be the bigger threat to people's health and the environment [p8, e6, e4]. Thus, the negative impacts from coal plants are projected to increase in the future (Koplitz et al., 2017).

\section{Private profits}

Economic actors have vested interests in the power sector. The objective of making profits of conglomerates - comprising energy companies and banks - is often pursued with coal. While some conglomerates historically focused on RE or fossil gas, the majority associates coal with large profits [sn1, si4, p7]. For generation companies, that is, for instance, due to the absence of price risk resulting from the automatic pass-through [si5], which ensures stable cash inflow from running coal plants (Ahmed, 2019). Other market distortions benefiting coal are neglecting external costs [e1, sn9] and easier application processes [si1]. Coal plants further allow for bigger margins due to their size, because "the bigger the project, the bigger the profit" [p7]. The profitable conditions for coal are accompanied by regulatory uncertainty for RE, for example, the Philippine feed-in tariffs' tight deadlines (Barroco \& Herrera, 2019).

Filipino banks seem to be more comfortable with financing coal projects than RE.The Philippines have a high credit rating and the domestic banks are highly liquid (Fitch Ratings, 2019, 2020) [si7, si2, e2]. Multilateral Development Banks rarely substitute domestic banks [e3, si2] and most Filipino coal developers are financed domestically (urgewald e.V., 2019). Wind and solar are often small projects with low margins [si2] and hold intrinsic uncertainty (Barroco \& Herrera, 2019). The latter manifests in high risks, for example, due to lengthy processes and the work with small, unexperienced local groups [si2, e7, e6, si5]. 
The banks themselves have limited experience with wind and solar [si7, p1, sn9, e7]. Furthermore, wind and solar are often merchant plants without PSAs that have to take the risk of the spot market [si1, si2, e6]. Banks, however, expect a PSA before providing financing, and for developers, it is difficult to close a PSA without financing [si1]. In the words of one interviewee, "PSA and financing for RE is like chicken and egg" [e1]. Thus, while companies see large stable profits in coal, investment in RE is considered less reliable.

Oligarchs owning the conglomerates and banks not only control the supply and demand of electricity but also influence policy-making in favor of coal [p1, p7, sn10, e4, sn8]. This is referred to as "regulatory capture" [si8] and "business and political entanglement" [sn1]. The conglomerates influence many of the legal and political institutions (Roxas \& Santiago, 2010), for example, by bankrolling electoral campaigns of politicians [sn5, p5, p7]. The companies can also directly take part in policy formulation [e2, p3]; Meralco, for instance, submitted comments on the net-metering rules (Energy Regulatory Commission, 2013). An example of lobbying is a recent coal tax reform that the Department of Finance promoted over the DOE with the main objective of increasing revenue for the "Build, Build, Build" program [sn7, sn9]. ${ }^{3}$ It was altered after lobbying from the private sector, especially from the oligarchs in the domestic mining sector (Cabuag, 2017; Jiao, 2017) [sn10]. ${ }^{4}$ An organization that brings together owners of different conglomerates is the Makati Business Club, one of the most prominent industry organizations with strong ties to politics [p5]. The conglomerates can further influence the discussion by creating pro-coal narratives that are taken up by the society and politicians [e6].

\section{Discussion and policy implications}

Coal use in the Filipino power sector is rising as a result of the interplay of various political economy factors. In the following, we describe why the arguments in favor of coal prevail against those in favor of alternative energy sources, such as renewables, and discuss how this is reflected in the recent policy process. We then provide some tentative conclusions on how the country's dependence on coal could be reduced. Finally, we discuss the effects of recent developments, in particular the COVID-19 pandemic.

\section{Conflicting objectives}

We identify a variety of objectives affecting decision-making in the power sector - those supporting the construction of coal-fired power plants are prevailing. Civil society actors advocate for a just transition to RE.This is in line with the country's high vulnerability to climate change and obvious advantages of renewables in terms of import dependence, local air and water pollution as well as comparatively low costs, especially for the provision of electricity access in remote areas. By contrast, most oligarchs in the power sector favor coal in view of the associated profits [sn1, si4, p7]. They own large conglomerates 
comprising generation companies as well as banks and influence policy-making [p1, sn10, e4, sn8]. The president and the DOE rely on the support of the oligarchs (McCoy, 2017) [sn5, p5, sn1] and support the construction of coal plants. Coal is seen as a prerequisite to meet the projected demand growth for economic development in general [sn4, p6, sn7, e8]: "We are predominantly growing through coal" [e4]. This is reflected in the sustainable framework of the central bank, which "supports economic growth [...] while reducing pressure on the environment" (Bangko Sentral ng Pilipinas, 2020) and thus prioritizes growth over environmental concerns. These conflicting objectives are also present on the local level, for example, in the province of Palawan:The construction of a coal plant has, after years of resistance by the civil society (Marquardt, 2015), been approved by the local government in 2019 because of a lack of electricity supply [sn5, si5, p9]. ${ }^{5}$ In line with the strong influence of conglomerates, the president and the DOE on energy policy formulation, sustainability often has to take a back seat to other objectives, which results in the buildup of coal-fired electricity generation.

\section{Policy process}

Public officials show reluctance to implement effective policies to initiate the transition to renewables and additionally foster competition in the power sector, among others due to the influence of powerful conglomerates. The Congress passed multiple laws, but the implementing rules and regulations by the DOE or other departments are often flawed and delayed [sn6, sn11, si8, si5, p2, p4]. Examples are the Electric Power Industry Reform Act from 2001 that aimed at the liberalization of the power sector and the Renewable Energy Act from 2008. Both are still not fully implemented [e5, sn6]. One stated reason is inertia due to the sheer number of involved stakeholders and the lack of coordination between them [sn2, si3, sn6]. Another reason is the power of oligarchs as demonstrated in the following example. The Competitive Selection Process for Power Supply Agreements (Department of Energy, 2015, 2018c) should reduce electricity prices and prevent "sweetheart deals", for example, between Meralco and their wholly owned generation company MGen [si8, p1]. The implementation was illegally postponed for ten months by the Energy Regulatory Commission (Supreme Court of the Philippines, 2019). In that time span, many PSAs were signed, including seven Meralco-affiliated agreements for more than 3500 GW of coal capacity - which then did not necessarily have the lowest costs [sn10, si8]. All four commissioners of the Energy Regulatory Commission were suspended because they were found guilty of giving benefits to Meralco and other companies (Nonato, 2017) [p7].

\section{Lessons for reducing coal dependence}

Policies to reduce the country's dependence on coal need to take the objectives of the most influential actors into account. One important finding of this study 
is the reluctance of many conglomerates to invest in renewables. Continuous declines in the costs of RE technologies could provide an important rationale for increased uptake in the future purely based on profit motives, that is even without taking benefits for the climate, local environmental quality as well as energy security into account. In addition, investments in RE could be incentivized by renewable resource maps by the DOE to guide investors [p6], long-term policy planning to reduce regulatory uncertainty [e3, sn10, e4, sn11, sn2] and de-risking mechanisms, for example, governmental collaterals [e1, e6, si2]. Interviewees further recommended to level the playing field, that is reducing artificial advantages for coal, such as the pass-through provisions for price fluctuations [si1, e5, si5, sn6, sn9, e8]. Options in this direction are fixed-price deliveries for PSAs [e1]. These can probably only be implemented if they are designed in a way that allows conglomerates to maintain their profits.

\section{The future of the electricity sector}

The future development of the power sector in the Philippines is uncertain. The US\$ 3.4 billion fund for economic stimulus and pandemic response does not contain dedicated green funding (Congress of the Philippines, 2020). However, the DOE stated in October 2020 that it will no longer accept applications for new coal plants (Lagare, 2020), lasting until the department determines the need for additional supply (The Online Citizen, 2020). On the international level, momentum for ambitious climate change mitigation measures is building up as major players, such as the EU, China, Japan as well as the new US president Joe Biden, have announced plans for "net zero" emissions. These global developments might also have repercussions for energy and climate policies in the Philippines. Policy-makers might hence now have a window of opportunity to lay the foundation for a clean energy transition.

\section{Acknowledgments}

First and foremost, the authors would like to thank all interview partners for sharing their insights and thus making this chapter possible. Support from Jens Marquardt in preparing the interview guideline is gratefully acknowledged. Great thanks to Björn Surborg for support in Metro Manila and Jan Steckel for supervision and reviewing the chapter. The authors would like to thank the participants of the following events for their valuable feedback: $\mathrm{PhD}$ workshop in June 2020 as part of the Dialogue on the Economics of Climate Change initiated by the BMBF - in particular Frank Wätzold; General Conference of the European Consortium for Political Research in August 2020 - in particular Andreas Goldthau; workshop on the political economy of coal in October 2020. Further thanks to Anna Kirchner and Antonella Bosio for excellent research assistance. The authors acknowledge funding from the German Federal Ministry of Education and Research (BMBF), funding code 01LA1826A (PEGASOS). N.M. gratefully acknowledges ideological and financial support 
of the Heinrich Böll Foundation. We finally would like to thank anonymous reviewers for their helpful comments.

\section{Appendix}

This chapter contains supplementary online material at https://www.mccberlin.net/pecoal/ch11.

\section{Notes}

1 This chapter draws on the article Manych and Jakob (2021). We gratefully acknowledge permission to reproduce parts of the content from Elsevier.

2 This chapter contains supplementary online material at mcc-berlin.net/pecoal/ch11.

3 The impact of the tax hike on the electricity tariffs is to this point unknown.

4 Another example is Solar Para Sa Bayan run by the son of then-senator Loren Legarda, which got a franchise for solar microgrids in non-serviced areas (Congress of the Philippines, 2018) [sn3, sn10].

5 Environmental groups together with the local community went to court to stop the construction (Chavez, 2020). The results are pending.

\section{References}

Ahmed, S. J. (2019). The Philippine Energy Transition. Institute for Energy Economics and Financial Analysis. http://ieefa.org/wp-content/uploads/2019/03/The-PhilippineEnergy-Transition_March-2019.pdf

Bangko Sentral ng Pilipinas. (2020). Circular No. 1085; Sustainable Finance Framework. www.bsp.gov.ph/downloads/regulations/attachments/2020/c1085.pdf

Barroco, J., \& Herrera, M. (2019). Clearing barriers to project finance for renewable energy in developing countries: A Philippines case study. Energy Policy, 135, 111008. https://doi.org/10.1016/j.enpol.2019.111008

Bertheau, P., \& Cader, C. (2019). Electricity sector planning for the Philippine islands: Considering centralized and decentralized supply options. Applied Energy, 251,113393. https://doi.org/10.1016/j.apenergy.2019.113393

Bogner, A., Littig, B., \& Menz,W. (2014). Interviews mit Experten. Springer Fachmedien Wiesbaden. https://doi.org/10.1007/978-3-531-19416-5

Brahim, S. P. (2014). Renewable energy and energy security in the Philippines. Energy Procedia, 52, 480-486. https://doi.org/10.1016/j.egypro.2014.07.101

Build Build Build. (2018). Philippine Infrastructure Transparency Portal. www.build. gov.ph/

Cabuag, V. (2017). Coal-tax increase 'discriminatory,' may trigger energy price spikeDMCI. BusinessMirror. https://businessmirror.com.ph/2017/11/29/coal-taxincrease-discriminatory-may-trigger-energy-price-spike\%c2\%ad-dmci/

Chapman, A., Stockwell, C., Hutfilter, U. F., Hare, B., Kahlen, L., Lui, S., Höhne, N., \& Barrer, R. (2019). Climate Governance: Assessment of the Government's Ability and Readiness to Transform the Philippines into a Zero Emissions Society. Climate Action Tracker. https://climateactiontracker.org/documents/663/2019-10-31_CAT_Climate Governance_Philippines.pdf 
Chavez, L. (2020). Philippine community goes to court to stop coal plant in ecological haven. Mongabay. https://news.mongabay.com/2020/09/philippinecommunity-goes-to-court-to-stop-coal-plant-in-ecological-haven/

Clark, R., Zucker, N., \& Urpelainen, J. (2020). The future of coal-fired power generation in Southeast Asia. Renewable and Sustainable Energy Reviews, 121, 109650. https://doi.org/10.1016/j.rser.2019.109650

Climate Change Commission. (2012). National Climate Change Action Plan 2011-2028. http://climate.emb.gov.ph/wp-content/uploads/2016/06/NCCAP-1.pdf

Climate Vulnerable Forum. (2015). Manila-Paris Declaration. www.thecvf.org/wpcontent/uploads/2015/11/ADOPTED_FOR_DISTRIB-Manila-ParisDeclaration1.pdf

CNN Philippines. (2020). Duterte claims victory in dismantling oligarchy in PH. CNN Philippines. www.cnnphilippines.com/news/2020/7/14/Duterte-oligarchy-martiallaw-ABS-CBN.html

Congress of the Philippines. (1999). Republic Act No. 8749, Philippine Clean Air Act of 1999. www.doh.gov.ph/sites/default/files/policies_and_laws/RA08749.pdf

Congress of the Philippines. (2001). Republic Act No. 9136, Electric Power Industry Reform Act of 2001 [Lawphil.net]. https://lawphil.net/statutes/repacts/ra2001/ra_9136_ 2001.html

Congress of the Philippines. (2008). Republic Act No. 9513, Renewable Energy Act of 2008 [Lawphil.net]. https://lawphil.net/statutes/repacts/ra2008/ra_9513_2008.html

Congress of the Philippines. (2018). Republican Act No. 11357. www.officialgazette.gov. ph/downloads/2019/07jul/20190731-RA-11357-RRD.pdf

Congress of the Philippines. (2019). Republic Act No. 11234, Energy Virtual One-Stop Shop Act. www.officialgazette.gov.ph/downloads/2019/03mar/20190308-RA11234-RRD.pdf

Congress of the Philippines. (2020). Republic Act No. 11494. www.officialgazette.gov.ph/ 2020/09/11/republic-act-no-11494/

Department of Energy. (2015). DOE Circular NO. DC2015-06-0008, Mandating All Distribution Utilities to Undergo Competitive Selection Process (CSP) in Securing Power Supply Agreements (PSA). www.doe.gov.ph/sites/default/files/pdf/issuances/dc 2015-06-0008.pdf

Department of Energy. (2016). Philippine Energy Plan 2016-2030. www.doe.gov. $\mathrm{ph} / \mathrm{pep}$

Department of Energy. (2017a). Coal Roadmap 2017-2040. www.doe.gov.ph/pep/ coal-roadmap-2017-2040

Department of Energy. (2017b). Energy Demand \& Supply Outlook. www.doe.gov.ph/ sites/default/files/pdf/pep/pep_volume_1_energy_demand_supply_outlook.pdf

Department of Energy. (2017c). Investment Opportunities in the Philippine Energy Sector. www.doe.gov.ph/sites/default/files/pdf/e_ipo/investment_opportunities_phil_ energy_sector.pdf

Department of Energy. (2017d). Philippine Energy Plan 2017-2040. www.doe.gov.ph/ pep/philippine-energy-plan-2017-2040

Department of Energy. (2017e). Sectoral Plans and Roadmaps. www.doe.gov.ph/sites/ default/files/pdf/pep/pep_volume_2_sectoral_plans_and_roadmaps.pdf

Department of Energy. (2018a). 32st Electric Power Industry Reform Act (EPIRA) Implementation Status Report. www.doe.gov.ph/sites/default/files/pdf/electric_ power/32nd_epira_report_april_2018.pdf 
Department of Energy. (2018b). Compendium of Philippine Energy Statistics and Information (1990-2016). www.doe.gov.ph/sites/default/files/pdf/energy_statistics/doe_compendium_energy_statistics.pdf

Department of Energy. (2018c). DOE Circular No. DC2018-02-0003, Adopting and Prescribing the Policy for the Competitive Selection Process in the Procurement by the Distribution Utilities of Power Supply Agreement for the Captiva Market. www.doe.gov. $\mathrm{ph} /$ sites/default/files/pdf/issuances/dc2018-02-0003.pdf

Department of Energy. (2019a). 2019 Power Statistics. www.doe.gov.ph/sites/default/ files/pdf/energy_statistics/2019_power_statistic_01_summary.pdf

Department of Energy. (2019b). DOE, Gencos: Collusion Didn't Cause Brownouts. www. doe.gov.ph/energist/doe-gencos-collusion-didn\%E2\%80\%99t-cause-brownouts

Department of Energy. (2020a). 2019 Coal Consumption.www.doe.gov.ph/sites/default/ files/pdf/energy_resources/2019-coal-consumption.PDF

Department of Energy. (2020b). DOE Organizational Structure. www.doe.gov.ph/doeorganizational-structure?ckattempt $=1$

Department of Energy. (2020c). Energy Situationer DRAFT. www.doe.gov.ph/sites/ default/files/pdf/announcements/1_Energy\%20Situationer_19Aug2020.pdf

Department of Energy. (2020d). List of Valid and Subsisting Accredited Coal Traders. www. doe.gov.ph/sites/default/files/pdf/energy_resources/2020_accredited_coal_ traders_august.pdf

Department of Environment and Natural Resources. (2007). Memorandum Circular No. 001, Series of 2007, Environmental Impact Assessment (EIA) Review Manual. https:// emb.gov.ph/wp-content/uploads/2016/06/EMB-MC-2007-001.pdf

Dressel, B. (2011). The Philippines: How much real democracy? International Political Science Review, 32(5), 529-545. https://doi.org/10.1177/0192512111417912

Duterte, R. R. (2020). Fifth State of the Nation Address. www.officialgazette.gov.ph/ 2020/07/27/rodrigo-roa-duterte-fifth-state-of-the-nation-address-july-27-2020/

Energy Regulatory Commission. (2013). Resolution No. 09, Series of 2013, A Resolution Adopting the Rules Enabling the Net-Metering Program for Renewable Energy. www.erc. gov.ph/IssuancesPage/1/0

Fitch Ratings. (2019). Philippine Banks 1 H19 Report Card. www.fitchratings.com/ research/banks/philippine-banks-1h19-report-card-03-09-2019

Fitch Ratings. (2020). Philippines Rating Report. www.fitchratings.com/research/ sovereigns/philippines-28-02-2020

Fuentes Hutfilter, U., Zimmer, A., Saeed, F., Hare, B., Aboumahboub, T., Kelischek, I., Schleussner, C.-F., Parra, P.Y., Ancygier, A., Brecha, R., Granadillos, J., Ganti, G.,Vyas, R., \& Schaeffer, M. (2019). Country profile Philippines; decarbonising South and South East Asia. Climate Analytics. https://climateanalytics.org/media/decarbonisingasia2019profile-philippines-climateanalytics.pdf

GIZ. (2019). EU-Philippines Access to Sustainable Energy Programme (ASEP)—Technical Assistance. www.giz.de/en/worldwide/62913.html

Global Energy Monitor. (2021). Global Coal Plant Tracker. https://globalenergymonitor. org/projects/global-coal-plant-tracker/

global witness. (2019). Defending the Philippines: Environmental Activists at the Mercy of Business at All Costs. www.globalwitness.org/en/campaigns/environmental-activists/ defending-philippines/

Gray, M., Kok, I., Ljungwaldh, S., \& Watson, L. (2018). Economic and Financial Risks of Coal Power in the Philippines. Carbon Tracker Initiative. www.carbontracker.org/wpcontent/uploads/2018/11/Economic-and-Financial-Risks-of-coal-power-in-ThePhilippines.pdf 
Holden,W. N. (2018).Typhoons, climate change, and climate injustice in the Philippines. Austrian Journal of South-East Asian Studies, 117-139. https://doi.org/10.14764/ 10.ASEAS-2018.1-7

IRENA. (2017). Renewables Readiness Assessment: The Philippines. International Renewable Energy Agency. www.irena.org/publications/2017/Mar/RenewablesReadiness-Assessment-The-Philippines

Jakob, M., Flachsland, C., Christoph Steckel, J., \& Urpelainen, J. (2020). Actors, objectives, context: A framework of the political economy of energy and climate policy applied to India, Indonesia, andVietnam. Energy Research \& Social Science, 70, 101775. https://doi.org/10.1016/j.erss.2020.101775

Jiao, C. (2017). Local and foreign coal companies face 400\% tax hike. CNN Philippines. https://cnnphilippines.com/news/2017/12/14/Local-and-foreign-coalcompanies-face-400-tax-hike.html

Koplitz, S. N., Jacob, D. J., Sulprizio, M. P., Myllyvirta, L., \& Reid, C. (2017). Burden of disease from rising coal-fired power plant emissions in Southeast Asia. Environmental Science \& Technology, 51(3), 1467-1476. https://doi.org/10.1021/ acs.est.6b03731

La Viña, A. G., Tan, J. M., Guanzon, T. I. M., Caleda, M. J., \& Ang, L. (2018). Navigating a trilemma: Energy security, equity, and sustainability in the Philippines' low-carbon transition. Energy Research \& Social Science, 35, 37-47. https://doi.org/10.1016/ j.erss.2017.10.039

Lagare, J. B. (2020). DoE issues ban on new coal plants. The Manila Times. www. manilatimes.net/2020/10/28/business/business-top/doe-issues-ban-on-new-coalplants/787454/

Lorenzana,L.M. C. (2020).The Philippine oligarchy. The Manila Time. www.manilatimes. net/2020/07/29/opinion/columnists/the-philippine-oligarchy/747380/

Maniego Jr., P. H. (2016). A Struggle between Coal and Renewable Energy in the Philippines. https:// us.boell.org/2016/06/17//struggle-between-coal-and-renewableenergy-philippines

Manych, N., \& Jakob, M. (2021). Why coal?-The political economy of the electricity sector in the Philippines. Energy for Sustainable Development, 62, 113-125. https://doi. org/10.1016/j.esd.2021.03.012.

Marquardt, J. (2015). Widerstand gegen den Kohlestrom auf Palawan. Das Dilemma des philippinischen Entwicklungsmodells. Südostasien.

Marquardt, J., \& Delina, L. L. (2019). Reimagining energy futures: Contributions from community sustainable energy transitions in Thailand and the Philippines. Energy Research \& Social Science, 49, 91-102. https://doi.org/10.1016/j.erss.2018.10.028

Marquardt, J., Steinbacher, K., \& Schreurs, M. (2016). Driving force or forced transition? Journal of Cleaner Production, 128, 22-33. https://doi.org/10.1016/j. jclepro.2015.06.080

McCoy, A. W. (Ed.). (2017). An Anarchy of Families: State and Family in the Philippines (Seventh Printing). Ateneo de Manila University Press.

Mendoza, C. B., Cayonte, D. D. D., Leabres, M. S., \& Manaligod, L. R. A. (2019). Understanding multidimensional energy poverty in the Philippines. Energy Policy, 133, 110886. https://doi.org/10.1016/j.enpol.2019.110886

Mendoza, R. U., Beja, E. L., Venida, V. S., \& Yap, D. B. (2012). Inequality in democracy: Insights from an empirical analysis of political dynasties in the 15th Philippine Congress. Philippine Political Science Journal, 33(2), 132-145. https://doi.org/10.1080/ 01154451.2012 .734094 
Mondal, M. A. H., Rosegrant, M., Ringler, C., Pradesha, A., \& Valmonte-Santos, R. (2018). The Philippines energy future and low-carbon development strategies. Energy, 147, 142-154. https://doi.org/10.1016/j.energy.2018.01.039

National Economic and Development Authority. (2017). Philippine Development Plan 2017-2022. http://pdp.neda.gov.ph/wp-content/uploads/2017/01/PDP-20172022.pdf

National Government Portal. (n.d.). About the government. Gov.Ph. Retrieved 21 July 2020, from www.gov.ph/about-the-government

Nonato, V. F. (2017). Ombudsman suspends all 4 ERC commissioners for one year. Inquirer.Net. https://newsinfo.inquirer.net/954147/ombudsman-erc-suspendedcommissioner-energy-regulatory-commission

Ong, G., \& Flores, H. (2016). Nothing wrong with coal plants - Duterte. Philstar. www. philstar.com/headlines/2016/03/21/1565436/nothing-wrong-coal-plants-duterte

President of the Philippines. (2017). Executive Order No. 30. www.officialgazette.gov.ph/ downloads/2017/06jun/20170628-EO-30-RRD.pdf

Purdey, J., Tadem, T. S. E., \& Tadem, E. C. (2016). Political dynasties in the Philippines: Persistent patterns, perennial problems. South East Asia Research, 24(3), 328-340. https://doi.org/10.1177/0967828X16659730

Quimpo, N. G. (2007). The Philippines: Political parties and corruption. Southeast Asian Affairs, 2007, 277-294. https://doi.org/10.1353/saa.2007.0019

Ravago, M.-L.V., Brucal, A. Z., Roumasset, J., \& Punongbayan, J. C. (2019). The role of power prices in structural transformation: Evidence from the Philippines. Journal of Asian Economics, 61, 20-33. https://doi.org/10.1016/j.asieco.2019.02.001

Ravago, M.-L.V., Fabella, R.V., Alonzo, R. P., Danao, R.A., \& Mapa, D. S. (2016). Filipino 2040 Energy: Power Security and Competitiveness. University of the Philippines and Energy Policy and Development Program (EPDP). https://mpra.ub.uni-muenchen. de/87721/1/MPRA_paper_87721.pdf

Ravago, M.-L.V., \& Roumasset, J. (2016). The Public Economics of Electricity Policy with Philippine Applications (Working Paper No. 16-13). University of Hawai i at Mānoa Department of Economics Working Paper Series. www.economics.hawaii.edu/ research/workingpapers/WP_16-13.pdf

Ravago, M.-L. V., Roumasset, J., \& Danao, R. A. (2018). Electricity policy in the Philippines: Overview and synthesis. Powering the Philippine Economy: Electricity Economics and Policy (pp.1-10). University of the Philippines Press.

Republic of the Philippines. (2015). Intended Nationally Determined Contributions. www 4.unfccc.int/sites/submissions/INDC/Published\%20Documents/Philippines/1/ Philippines\%20-\%20Final\%20INDC\%20submission.pdf

Romero, P. (2019). Senate to probe Philippine's nuclear energy program. Philstar. www.philstar.com/headlines/2019/10/14/1960013/senate-probe-philippinesnuclear-energy-program

Roxas, F., \& Santiago, A. (2010). Broken dreams: Unmet expectations of investors in the Philippine electricity restructuring and privatization. Energy Policy, 38(11), 72697277. https://doi.org/10.1016/j.enpol.2010.08.003

Rudnick, H., \& Velasquez, C. (2019). Learning from Developing Country Power Market Experiences: The Case of the Philippines (Policy Research Working Paper No. WPS8721). World Bank Group. https://documents.worldbank.org/en/publication/documents-reports/documentdetail/428331548771494859/learning-fromdeveloping-country-power-market-experiences-the-case-of-the-philippines 
Saculsan, P. G., \& Mori, A. (2020). Why developing countries go through an unsustainable energy transition pathway? The case of the Philippines from a political economic perspective. Journal of Sustainability Research, 2(2). https://doi.org/10.20900/ jsr20200012

Senate of the Philippines. (2019a). 18th Congress Committee Chairmanship. www.senate. gov.ph/committee/ctte_list18th.pdf

Senate of the Philippines. (2019b). Senate Bill No. 2218, Microgrid Systems Act. www. senate.gov.ph/lisdata/2985226540!.pdf

Shearer, C., Mathew-Shah, N., Myllyvirta, L., Yu, A., \& Nace, T. (2018). Boom and Bust 2018:Tracking the global Coal Plant Pipeline. CoalSwarm, Greenpeace USA, and Sierra Club. https://endcoal.org/wp-content/uploads/2018/03/BoomAndBust_2018_ r6.pdf

Supreme Court of the Philippines. (2019). Supreme Court Orders all Power Supply Agreements Submitted by Distribution Utilities with ERC on or after 30 June 2015 to Undergo Competitive Selection Process. http://sc.judiciary.gov.ph/3311/

The Online Citizen. (2020). Philippines DOE halts coal projects, local CSOs think that it can do more. The Online Citizen. www.onlinecitizenasia.com/2020/10/29/ philippines-doe-halts-coal-projects-local-csos-think-that-it-can-do-more/

The Philippine Star. (2017). Power sector at risk from higher coal tax. Philstar. www. philstar.com/business/2017/12/04/1765245/power-sector-risk-higher-coal-tax

The World Bank. (2014). Electric Power Consumption (kWh Per Capita)_Philippines. https://data.worldbank.org/indicator/EG.USE.ELEC.KH.PC?most_recent_value_ desc $=$ true\&locations $=\mathrm{PH}$

The World Bank. (2019a). Country Profile Philippines. https://databank.worldbank. org/views/reports/reportwidget.aspx?Report_Name $=$ CountryProfile $\& I d=$ $\mathrm{b} 450 \mathrm{fd} 57 \& \mathrm{tbar}=\mathrm{y} \& \mathrm{dd}=\mathrm{y} \& \mathrm{inf}=\mathrm{n} \& \mathrm{zm}=\mathrm{n} \&$ country $=\mathrm{PHL}$

The World Bank. (2019b). World Development Indicators: Population Dynamics. http://wdi. worldbank.org/table/2.1

UNFCCC. (2020). NDC Registry (Interim). www4.unfccc.int/sites/NDCStaging/ Pages/All.aspx

urgewald e.V. (2019). Coal Financers.

Verzola, R. S. (2018). MicroRenewables 8. CREST, Friedrich-Ebert-Stiftung.

Verzola, R. S., Logarta Jr., J. D., \& Maniego Jr., P. H. (2017). Towards a Just Transition in the Philippine Electricity Sector-Challenges and Opportunities. http://library.fes.de/pdffiles/bueros/philippinen/14215.pdf

Wong, P. N. (2010). The art of governing the self and others in the Christian Philippines. Journal of International and Global Studies, 1(2), 110-146.

World Values Survey. (2014). Wave 6: 2010-2014. www.worldvaluessurvey.org/ WVSContents.jsp

Yilmaz, S., \& Venugopal, V. (2013). Local government discretion and accountability in Philippines. Journal of International Development, 25(2), 227-250. https://doi.org/ $10.1002 /$ jid. 1687 